\title{
HIGHER PLANTS IN A BIOLOGICAL LIFE SUPPORT SYSTEM FOR MAN
}

\author{
I. Ye. IVANOVA, T. A. DERENDIAYEVA, G. I. MELESHKO, Ye. Ya. SHEPELEV
}

Institute for Biomedical Problems, Moscow, Russia

Received June 5, 1995

Accepted June 6, 1996

\begin{abstract}
Ivanova I. Ye., T. A. Derendiayeva, G. I. Meleshko, Ye. Ya. Shepelev: Higher Plants in a Biological Life Support System for Man. Acta vet. Brno 1996, 65: 27-32.

A model of human biological life support system (BLSS) was created with a photoautotrophic link including unicellular algae and higher plants having an equal oxygen production. This system model supported the vital activities of two people at the biomass regeneration of $92 \%$ from that consumed by them. The plant cultures studied were wheat grown on $11.25 \mathrm{~m}^{2}$ (of a total $15 \mathrm{~m}^{2}$ ) and several vegetable species. The total photosynthetic productivity of the plants was high, stable over the studied time span, and independent on the composition of the system. However, the grain productivity of wheat decreased periodically, and during certain harvests it decreased to almost zero. A detailed analysis revealed that this decrease was not caused by any of the system's adjacent links as a similar decrease in yield was also found in the control period with an autonomous growth of the plants in a closed volume of a chamber.

Inclusion of higher plants into BLSS led to a considerable improvement od food supply regeneration for man as compared to the previous model with only $26 \%$ regeneration effect. This inclusion did not exert any marked effect upon the general closure of the cycle. However, the biological value of the food for man was increased dramatically. This improvement is the main goal of designing and operating such BLSS systems.
\end{abstract}

Regeneration, ecosystem, photosynthesis, photoautotroph link, unicellular algae, higher plants

The prospect of long-term existence of man outside the Earth's biosphere (interplanetary flights, lunar and planetary bases) is connected with creating an artificial environment with the help of regenerating it from the products of vital activity. This environment must correspond to the evolutionarily conditioned biological needs of the humans and to provide their lives for generations. The fact of adaptive biology shows that the full-value environment for humans and other terrestrial organisms is the natural environment of the Earth. In order to recreate that environment artificially it is necessary to reproduce the mechanisms existing on Earth, i. e. to form closed ecological systems including man.

The lack of our knowledge about the natural environment of the humans prevents us from reproducing it by non-biological means, even if it were possible.

The investigation of the problem of creating biological life-support systems (BLSS) of man began as early as in the 60ies. By the present time, experimental BLSS models have been created with different structures and different degrees of the cycle closure.

The creation of the systems was based on the ecological concept according to which strategy and tactics were worked out providing the organisms and populations were studied and then united into biocenoses, including also humans. The main method of solving the problem was the method of experimental modelling from the simple to the complex (Rashevski 1966).

\section{Materials and Methods}

A sealed volume equipped for human sojourn inside it, was connected with a photosynthetic reactor containing the unicellular algae Chlorella and with a conservatory containing higher plants so that they made up a single system with common gas exchange and water balance. The research into the main characteristics of the system was conducted step by step: first „man - algae“, then „man - higher plants“. 


\section{Results and Discussion}

The simplest system model included man, unicellular algae and microorganisms. The microorganisms were presented in the system as an accompanying factor in all biological links, and also as an independent link of biological mineralization of urine with the return to the cycle of water, carbon dioxide and nitrogen. Besides biological links the model included some physical and chemical processes: purification, disinfection and conditioning of potable water from the condensate at the output of the photosynthetic reactor, and the centers of thermic processing of the algae biomass, solid human wastes and urine aimed at the return to the cycle of the free water.

From outside, the system received mineral elements for the nutrition of algae, and sublimed products of the food ration with the addition of $50 \mathrm{~g}$ of dry algae biomass used in the ration as a separate dish. The ,input" and „output" masses were carefully balanced. On the whole, such a system presents a maximally reduced (simplified) ecosystem in which the autotroph function is performed by a single plant species, Chlorella, and its metabolic antipode man.

In spite of the simplicity of the biocenotic structure, a large percentage of matter regeneration was achieved in such a system. It provided $100 \%$ satisfaction of the human need for oxygen and water without any supplies of them, the utilization by the algae of 95-96 $\%$ of carbon dioxide excreted by man, the link of urine mineralization, the reproduction of $8-10 \%$ of food elements. The total percentage of the matter regeneration amounted to $90 \%$ (Table 1).

Table 1

The degree of matter regeneration in two biological life support system models

\begin{tabular}{|c|c|c|c|c|c|}
\hline \multirow[t]{3}{*}{ Matter } & \multirow[t]{3}{*}{$\begin{array}{l}\text { Consumption } \\
\mathrm{g}^{\prime} \text { day }\end{array}$} & \multicolumn{2}{|c|}{$\begin{array}{l}\text { Model: man - algae- } \\
\text { mineralization }\end{array}$} & \multicolumn{2}{|c|}{$\begin{array}{l}\text { Model: man - algae- } \\
\text { mineralization - higher plants }\end{array}$} \\
\hline & & \multicolumn{4}{|c|}{$\frac{1}{\text { regenerated }}$} \\
\hline & & $\mathrm{g} / \mathrm{day}^{-1}$ & $\%$ & $\mathrm{~g} / \mathrm{day}^{-1}$ & $\%$ \\
\hline Oxygen & 755 & 755 & 100 & 755 & 100 \\
\hline Food & 530 & 50 & 9 & 138 & 26 \\
\hline Water & 3400 & 3400 & 100 & 3400 & 100 \\
\hline Total & 4685 & 4205 & 90 & 4293 & 92 \\
\hline
\end{tabular}

The model based on algae does not correspond to the classical pyramid of Od u m (1976) for the ground ecosystems. Here $400-450 \mathrm{~g}$ of dry matter of algae provide for the gas exchange of man whose biomass is 40 times larger, and for his nutritional needs, if he could consume nothing but the algae biomass. The study of the basic characteristics of human environment formed in the given model has shown that the algae have performed a series of additional functions: purification of the atmosphere from soluble in water gaseous admixtures, stabilization of the total quantity and composition of the aerial microflora, maintaining of the aeroionic composition of the atmosphere (Meles h ko and Shepelev $1987,1988)$. The efficiency and stability of this model allowed to proceed to implementation of models with a more complex structure including higher plants.

The model of BLSS based on Chlorella and higher plants

This BLSS model combines the previously described model based on Chlorella with components of utilization of organic wastes, and the link of higher plants. It is represented by 
a conservatory with the crop area of $15 \mathrm{~m}^{2}$ in a general hermetic complex including section for the testers and the air conditioning system. The volume of the complex was automatically connected with the complex ,man - algae“. The link of the higher plants was represented by the incessant sowing of wheat and vegetable cultures; the structure of the link is shown in Table 2. At the beginning of the experiment, the illumination on the level of the wheat crop area remained 114 W/m $\mathrm{m}^{2} \mathrm{FAR}$; the density of the wheat crops amounted to 1150 plants per $\mathrm{m}^{2}$. For vegetable cultures it was the following: 75 for beets, 188 for carrots, 12 for cabbage, 147-210 for peas. At the 45th day of the experiment, the wheat crop density increased to 1730 plants per $\mathrm{m}^{2}$, and the illumination grew gradually, and by the 90 th day of the experiment it amounted to $200 \mathrm{~W} / \mathrm{m}^{2} \mathrm{FAR}$.

Table 2

Crop structure in the higher plant link

\begin{tabular}{|l|c|c|c|}
\hline Culture & Crop area $\left(\mathrm{m}^{2}\right)$ & Harvest period (days) & Plants harvest (days) \\
\hline Wheat & 11,25 & 9 & 65 \\
Beets & 0,62 & 8 & 77 \\
Carrots & 0,63 & 8 & 77 \\
Cabbage & 1,25 & 7 & 63 \\
Peas & 1,0 & 7 & 53 \\
\hline Seed-plot & 0,25 & - & - \\
\hline
\end{tabular}

All the plants were grown by the substratumless method with a periodic input of the nutritive solution to the roots zone every 15-18 minutes. The frequency of the harvest selection (the rate of conveyor sowing) was 5-9 days for different cultures. The vegetable plants had the same tank with the nutritive solution separate from the nutritive solution for the wheat. The correction of the composition of the nutritive solution was made twice a week. Its $\mathrm{pH}$ was maintained at 5-5.8. The air temperature in the conservatory was maintained on the level of $22-25^{\circ} \mathrm{C}$, the relative humidity was kept between $55-70 \%$, the concentration of carbon dioxide $0.35 \%$ during the functioning of the conservatory (without man). In the course of water disappearance, unchanged nutritive solution was supplied by the condensate when the transpirational water of the plants gathered in the system of the air conditioning of the conservatory air.

The functional participation of higher plants in the BLSS model was formed step by step. At first it was connected with urine mineralization and thermic drying of all organic wastes in the stream of air which then went to the nutritive solution for the wheat and returned form there to the general atmosphere. Then one tester was introduced into the system, and 30 days later another one together with the Chlorella-based system which provided for him. The total duration of the model's work with the participation of the tester was 45 days.

The functional characteristics of the higher plant link were estimated by comparison of the studied indices during the experimental period with the indices of the control period of the autonomous work of the link. The data on plant productivity are given in Table 3. It shows that the productivity of all plants except carrots decreased during the experimental period, and the economically useful part of the harvest diminished in the total biomass. It is also important, though not explained yet, that the productivity of the plants during the control period was considerably smaller than at their being grown in open models. The same results were obtained in the hermetic conservatory BIOS- 3 at the Institute of Physics of the Siberian Department of the Academy of Science of the USSR (Li s o v s ky 1975). We are not inclined to see a mere coincidence here. All the metallic equipment in which the models were placed 
Table 3

Productivity of plants, $\mathrm{g} / \mathrm{m}^{2} / \mathrm{day}$

\begin{tabular}{|l|l|c|c|}
\hline Culture & Condition & Useful & Total \\
\hline Wheat & Control & 5.2 & 25.8 \\
& Experiment & 4.6 & 32.8 \\
Peas & Control & 3.4 & 12.8 \\
& Experiment & 2.3 & 13.0 \\
Beets & Control & 3.4 & 8.4 \\
& Experiment & 2.3 & 5.0 \\
Carrots & Control & 6.0 & 11.0 \\
& Experiment & 6.3 & 9.7 \\
Cabbage & Control & 11.5 & 12.8 \\
& Experiment & 10.3 & 11.7 \\
\hline
\end{tabular}

was grounded according to the rules of electrical security. This is a possible reason of the observed phenomenon. We mean the electrostatic field of Earth, the positive potential of the atmosphere as related to the Earth's surface, the tension of which near Earth's surface amounts to $130 \mathrm{~V} / \mathrm{m}$. In the BLSS models, the plants are deprived of this historically constant and maybe important condition. It is possible that the loss of this constant terrestrial factor in space flight may generate further problems for BLSS in the future, as it has taken place in connection with the loss of Earth's gravity.

The dynamics of the wheat productivity in grain and in total biomass during the control period and the experiment period is shown in Fig. 1. The data are given from the article by I. Ye. Ivanova et al. During the experimental periods, the total photosynthetic productivity of the wheat plants has considerably grown in connection with the increase of the crop density and of illumination. This shows a normal reaction of the plants to the increase of illumination outside the area of light saturation. The largest values of the productivity were obtained during the period of two testers and the Chlorella link being present within the system, as well as the link of urine mineralization and drying the organic wastes, i. e. the period of the maximum load of the adjacent links of the system.

A less stable picture was observed at the analysis of wheat productivity in grain (the lower curve in Fig. 1). At the 55th, 62nd and 69th days, as well as at the end of the experiment, the grain productivity was reduced almost to zero. However, after the first three, cases of the ears being empty at the 55-69th day there were 4 full-value harvests with a productivity greater than in the control and than at the

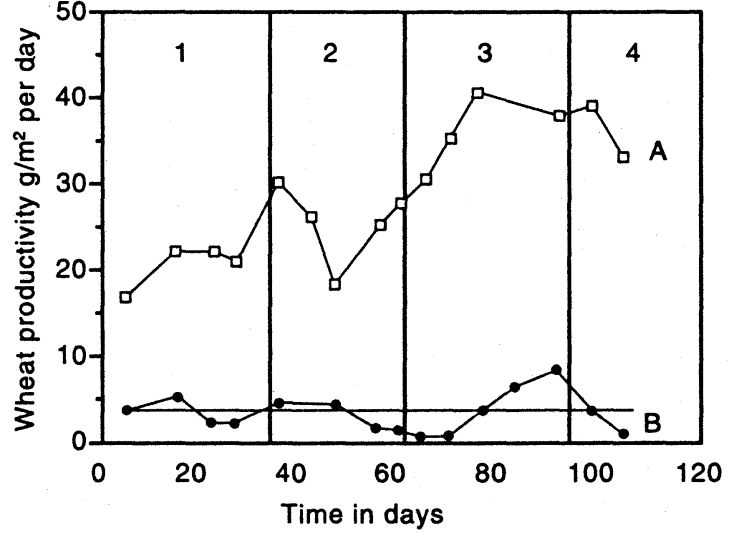

Fig. 1. Dynamics of wheat productivity with respect to total biomass (A) and grain (B) during various stages of BLSS model formation

1. Independent cultivation of wheat, control period.

2. Merging of the greenhouse atmosphere and that of the urine mineralization system.

3. Inclusion of the inhabited module with a single human subject.

4. Inclusion of the photosynthetic reactor with Chlorella and a second human subject. 
beginning of the experimental period. The reason for harvest failure (emptiness of wheat ears) seems not to be inherent to the system and remains unknown. However, the reasons cannot be connected with any of the adjacent links of the system which were included into it later. The cases of a decrease of the wheat harvest were observed also in the control period at the autonomous plant growing in the closed volume of a chamber.

Thus the maintaining of the general photosynthetic plant productivity combined with such impairments of the morphogenetic processes which lead to a considerable decrease of the useful part of the harvest, show the complex nature of the effects the reasons of which are not yet possible to analyze but are of scientific and practical interest for further study. At any rate, the obtained results show that the criterion of the photosynthetic productivity for the higher plants link does not reflect the criterion of optimum of this link while it is meant mainly for reproducing food.

In the experimental period, $432 \mathrm{~g}$ of dry plant biomass was synthesized daily, including $86 \mathrm{~g}$ of economically useful parts, of which there was $54 \mathrm{~g}$ of wheat and $32 \mathrm{~g}$ of vegetables.

In the given experiment, with the aim of the maximum utilization of the plant biomass in the food ration of humans, the food matters were extracted from the plant wastes traditionally not used - the tops of carrots, beets, peas, the wastes of cabbage. The plant mass was mechanically chopped ant the cell juice was extracted from the mass by pressing; its quantity amounted to $60 \%$ of the initial humidity of the wastes. The electric impulse processing of the chopped mass increased the output of the juice to $80-85 \%$ of the initial humidity; the dry matter of the juice contained up to $40 \%$ of carbohydrates and $18-30 \%$ od protein (Gurye va 1982).

As a result, the actual ration of the tester contained average $137 \mathrm{~g}$ of dry matter of biomass reproduced in the link, including $50 \mathrm{~g}$ of Chlorella biomass at the energy value of 454 large calories per day. This made up $26 \%$ of the food ration of humans by weight, and $19 \%$ by calorific value. The total biomass reproduced in the system which was included into the tester's ration contained $68 \mathrm{~g}$ of carbohydrates and $37 \mathrm{~g}$ of protein, $25 \mathrm{~g}$ of which were Chlorella proteins.

The determining of the main parameters of protein exchange of testers has shown an absence of any considerable changes, and the oscillation of excretion of nitrogen in urine corresponded to the oscillation of the total quantity of nitrogen consumed with the food.

The introduction of higher plants into the system did not lead to a considerable increase of the degree of the system's closure in food, while its part in the whole cycle is comparatively small. The degree of food regeneration increased as compared to the algae model only to $25 \%$ of the ration. But the biological value of the food ration grew considerably, which is the main goal of creating such systems. Including of higher plants into the system made it possible also to optimize the gas-exchange characteristics of the system. At the equal productivity of algae and higher plants, the total value of the assimilation coefficient increased, and became closer to the respiration coefficient of man. As a result, the formerly noted disbalance of oxygen and carbon dioxide in the system's atmosphere diminished to a minimum, and amounted to $1 \%$. The total closure of the matter cycle in the system increased to $92 \%$ (Table 1 ).

The passing to BLSS models with higher plants helps to solve the problem of the acceptable food chain of man, but it brings the system back to the structure of ground-based biocenoses in which the plant biomass, at a sufficient closure in food, must exceed the mass of heterotroph organisms, including man, by dozens of times. Probably in working out BLSS used in the conditions of limited space objects, the most optimal combination for the photoautotroph link will be that of higher plants and unicellular algae. 


\section{Vyššie rastliny v biologickom systéme zabezpečenia života}

Bol vytvorený model biologického systému zabezpečenia života pre človeka s fotoautotrofným spojom, zahrnujúcim jednobunečné riasy a vyššie rastliny s rovnakou produkciou kyslíka. Tento systémový model podporil vitálne aktivity dvoch Iudí pri $92 \%$ regenerácii hmoty $\mathrm{z}$ hmoty nimi konzumovanej. Sledované rastlinné kultúry pozostávali $\mathrm{z}$ pšenice, pestovanej na ploche $11,25 \mathrm{~m}^{2} \mathrm{z}$ celkovej plochy $15 \mathrm{~m}^{2}$, a z niekolkých druhov zeleniny. Celková fotosyntetická produktivita rastlín bola vysoká, stabilná a nezávisela na zložení systému. Produkcia zrna pšenice však periodicky klesala, pri niektorých úrodách až na nulu. Analýza výsledkov ukázala, že tento pokles nebol vyvolaný prídavnými súčastami systému, pretože podobný pokles nastal v kontrolnom období s autonómnym rastom rastlín v uzavretom priestore komory.

Zahrnutie vyšších rastlín do systému viedlo k podstatnému zlepšeniu zloženia potravy pre človeka, pretože v predchádzajúcom pokuse bol zaznamenaný regeneračný efekt iba $26 \%$. Zahrnutie vyšších rastlín do systému nemalo žiadny vplyv na uzavrenie cyklu, avšak biologická hodnota potravy pre človeka sa podstatne zvýšila. Toto zlepšenie bolo hlavným cielom vývoja a použitia systému zabezpečenia života.

\section{Высшие растения в биологической системе жизнеобеспечения человека}

Создана модель биологической системы жизнеобеспечения (ВСЖО) человека, в которой фотоавтотрофное звено включает одноклеточные водоросли и высшие растения при равной производительности их по кислороду. Модель системы обеспечивала жизнедеятельность 2-х человек при степени регенерации веществ $92 \%$ от потребляемых человеком. Растения были представлены в основном пшеницей $11,25 \mathrm{~m}^{2}$ (при общей посевной площади $15 \mathrm{~m}^{2}$ ) и овощными культурами. Общая фотосинтетическая продуктивность растений была высокой, устойчивость во времени и не зависела от состава системы. Продуктивность пшеницы по зерну периодически падала и в отдельные съемы урожая (конвейерный способ выращивания) снисжалась практически до нуля. Причиной была пустозерность колоса. Анализ показал, что причины не связаны ни с одним из смежных звеньев системы, поскольку случаи падения урожая наблюдались и в контгрольном периоде при автономном выращивании растений в замкнутом объеме камеры.

Включение в состав модели БСЖО высших растений привело к увеличению степени регенерации пищи по сравнению с предыдущей моделью »человек-одноклеточные водоросли-микроорганизмы « до 26 \% от массы рациона. Это не отразилось существенным образом на общей замкнутости круговорота. Однако биологическая полноценность рациона питания человека существенно возросла, что является основной челью при создании таких систем.

\section{References}

GURYEVA, T. S.1982: Izuchenie vosmozhnosti ispolzovanija listo-steblovoy massy vysshih rasteniy dlia poluchenia pisshevyh vesshestv v sisteme zhizneobespechenija cheloveka. Autoref. Ph.D. Thesis, Moskva, IMPB MZ RF, 37 p.

IVANOVA, I. Ye., DERENDIAYEVA, T. A., SHAIDOROV, Yu. I., SHEPELEV, Ye.Ya. 1989: Zveno vysshih rastenij v sostave BSZO cheloveka. Kosmicheskaya biologiya i aviakosmicheskaiya medicina. Moskva, No.6:59-64

LISOVSKI G. M. 1975: Phototrophy kak zveno zamknutoi ekologicheskoi sistemy, vkliuchajuschej cheloveka. Autoref. dokt. Thesis., Novosibirsk, 45p.

MELESHKO, G. I., SHEPELEV, Ye. Ya 1987: Biologicheskiye sistemy zhizneobespecheniya. In: Kosmicheskaya biologia i medicina. Moskva, Nauka, pp.123-147

MELESHKO, G. I., SHEPELEV, Ye.Ya. 1988: Biologicheskiye sistemy zhizneobespecheniya. Kosmicheskaya biologia i aviakosmicheskaya medicina, Moskva, No.6:30-36

ODUM, E.1976: Osnovy ekologii. Moskva.

RASHEVSKI, N. 1966: Nekotoriye medicinskiye aspekty metematicheskoi biologii. Moskva, 293 p. 